Int. J. Electrochem. Sci., 15 (2020) $188-207$

\title{
Evaluation of the Inhibition Effect of Some Novel Organic Compounds (phenol derivatives) for Corrosion of $\alpha$-brass in Acid Solutions
}

\author{
A. S. Fouda ${ }^{1, *}$, F. M. El-Taweel ${ }^{2}$, N. H. Mohamed ${ }^{1}$ \\ ${ }^{1}$ Department of Chemistry, Faculty of Science, El-Mansoura University, El-Mansoura-35516, Egypt, \\ ${ }^{2}$ Department of Chemistry, Faculty of Science, Damietta University \\ *E-mail: asfouda@hotmail.com, asfouda@mans.edu.eg
}

doi: $10.20964 / 2020.01 .30$

Received: 5 September 2019 / Accepted: 11 October 2019 / Published: 30 November 2019

The influence of the addition of some organic compounds (OCs) on the corrosion of $\alpha$-brass immersed in $1 \mathrm{M} \mathrm{HNO}_{3}$ were studied. Gravimetric and electrochemical (AC impedance (EIS), electrochemical frequency modulation (EFM) and polarization (PP)) tests were used separately for the experimental investigation. The protection efficiency of organic inhibitors improves with a rise in concentration and the temperature range from $25^{\circ} \mathrm{C}$ to $50^{\circ} \mathrm{C}$. PP tests also designated that organic inhibitors acted as mixedkind inhibitors. Surface investigation utilized atomic force microscope (AFM) displays an important morphological development on the $\alpha$-brass surface with the adding of the inhibitor. Adsorption isotherm showed that inhibitor protection mechanism followed the Langmuir isotherm model. Correlation among protection efficiencies and molecular orbital energy was a study of Density functional theory (DFT).

Keywords: $\alpha$-Brass corrosion, $\mathrm{HNO}_{3}$, Organic compounds, PP, EFM, EIS

\section{$\underline{\text { FULL TEXT }}$}

(C) 2020 The Authors. Published by ESG (www.electrochemsci.org). This article is an open access article distributed under the terms and conditions of the Creative Commons Attribution license (http://creativecommons.org/licenses/by/4.0/). 